\title{
Metode Diskusi dalam Pembelajaran Pendidikan Agama Islam
}

\author{
SYAHRAINI TAMBAK \\ Fakultas Agama Islam (FAI) Universitas Islam Riau (UIR) Pekanbaru \\ Jl. Kaharuddin Nasution, No. 113, Perhentian Marpoyan Pekanbaru 28284 \\ e-mail: syahraini_tambak@yahoo.co.id
}

\begin{abstract}
Abstrak: Ada banyak metode dalam pengajaran yang diterapkan oleh guru di sekolah. Salah satunya adalah metode diskusi. Metode ini menekankan pada interaksi antara sesama peserta didik dan juga guru dalam membahas atau mencari solusi terhadap materi pembelajaran. Jika dilaksanakan secara tepat, metode diskusi ini dapat merangsang peserta didik berfikir atau mengeluarkan pendapat sendiri sehingga juga akan melatih peserta didik untuk berfikir kritis dan percaya diri. Dalam pembelajaran pendidikan agama islam, metode diskusi bukanlah hanya percakapan atau debat biasa saja, tetapi diskusi timbul karena ada masalah yang memerlukan jawaban atau pendapat yang bermacam-macam. Hal ini perlu bagi peserta didik kelak, bukan saja karena manusia senantiasa dihadapkan pada berbagai persoalan yang tidak dapat dipecahkan seorang diri, melainkan juga karena melalui kerja sama atau musyawarah mungkin diperoleh suatu pemecahan yang lebih baik. Penerapan metode diskusi yang dilakukan oleh peserta didik terutama dengan bimbingan guru dalam pembelajaran pendidikan agama islam dipercaya sebagai salah satu metode yang tepat dalam menyalurkan ilmu yang bermanfaat dan pemahaman yang lebih mendalam.
\end{abstract}

Kata kunci: Metode diskusi, pemecahan masalah, pembelajaran PAI.

\section{PENDAHULUAN}

Diskusi merupakan sebuah interaksi komunikasi antara dua orang atau lebih. Biasanya komunikasi antara orang-orang tersebut berupa salah satu ilmu atau pengetahuan dasar yang akhirnya akan memberikan rasa pemahaman yang baik dan benar.

Metode diskusi dalam pembelajaran pendidikan Islam sudah lama dikenal. Metode diskusi ini bertujuan untuk dapat menyadari dan menguji bukti-bukti sistem nilai, pendapat dan respon dari suatu gagasan sendiri atau orang lain. Menguji secara kolektif tentang suatu gagasan yang dikemukakan orang lain. Untuk bertukar pikiran dan ide, belajar mengungkapkan serta menanggapi keterangan yang relevan. Mengaitkan data dan keadaan dari berbagai pandangan orang lain dan latar belakangnya berbeda-beda. Penguasaan guru pendidikan agama Islam terhadap metode diskusi menjadi penting untuk mewujudkan peserta didik memiliki kemampuan berbicara, menyampaikan pendapat, menanggapi pendapat peserta didik lain, dan 
menjadikan peserta didik memiliki sikap demokratis.

\section{PENGERTIAN METODE DISKUSI}

Diskusi dari aspek bahasa berarti tukar pikiran antara dua orang atau lebih untuk menyelesaikan suatu persoalan. Kata diskusi berasal dari Bahasa Latin yaitu "discussus" yang berarti "tu examine", "investigate" (memeriksa, menyelidiki). Secara umum diskusi adalah suatu proses yang melibatkan dua orang atau lebih undividu yang berintegrasi secara verbal dan saling berhadapan muka mengenai tujuan atau mempertahankan pendapat atau pemecahan masalah (Nizar \& Hasibuan, 2011: 60).

Metode diskusi merupakan suatu cara mengajar yang bercirikan oleh suatu keterikatan pada suatu topik atau pokok pertanyaan atau problem. Di mana para anggota diskusi dengan jujur berusaha mencapai atau memperoleh suatu keputusan atau pendapat yang disepakati bersama (Hamalik, 2001: 45). Dalam metode diskusi guru dapat membimbing dan mendidik peserta didik untuk hidup dalam suasana yang penuh tanggung jawab, setiap orang yang berbicara atau mengemukakan pendapat harus berdasarkan prinsipprinsip tertentu yang dapat dipertanggungjawabkan.

Kata 'diskusi' ditinjau dari aspek istilah atau pendapat para ahli pada dasarnya ialah tukar menukar informasi, pendapat, dan unsur-unsur pengalaman secara teratur dengan maksud untuk mendapat pengertian bersama yang lebih jelas dan lebih teliti tentang sesuatu atau untuk mempersiapkan dan merampungkan keputusan berasama (Sudjana, 1995: 79). Menurut Martinis Yamin (2011: 49), metode diskusi merupakan interaksi antara peserta didik dan peserta didik atau peserta didik dengan guru untuk menganalisis, memecahkan masalah, menggali atau memperdebatkan topik atau permasalahan tertentu.

Menurut Abdul Rachman Shaleh metode diskusi adalah suatu cara penguasaan bahan pelajaran melalui tukar menukar pendapat berdasarkan pengetahuan dan pengalaman yang telah diperoleh guna memecahkan suatu masalah. Dengan kata lain, dalam metode ini peserta didik mempelajari sesuatu melalui cara musyawarah di antara sesama mereka di bawah pimpinan atau bimbingan guru. Hal ini perlu bagi peserta didik kelak, bukan saja karena manusia senantiasa dihadapkan pada berbagai persoalan yang tidak dapat dipecahkan seorang diri, melainkan juga karena melalui kerja sama atau musyawarah mungkin diperoleh suatu pemecahan yang lebih baik (Shaleh, 2006: 195).

Metode diskusi merupakan proses saling bertukar pikiran antara dua orang atau lebih. Melalui proses ini, kedua belah pihak akan saling berdialog dan mengemukakan pandangannya secara argumentatatif. Proses ini dilakukan dengan penuh keterbukaan dan persaudaraan. Tujuan utamanya adalah untuk mencari kebenaran. Metode ini akan mampu merespon daya intelektual peserta didik untuk melakukan analisis kritis dan menumbuhkan kepercayaan diri dalam membangun sebuah pemikiran yang dapat dipertanggungjawabkan dan dimanfaatkan oleh seluruh umat manusia (Nizar, 2008: 178).

Dalam dunia pendidikan, metode diskusi ini mendapat perhatian yang cukup besar karena dengan diskusi merangsang murid-murid berfikir atau mengeluarkan pendapat sendiri. Ini pun lazim berlaku dalam kehidupan keluarga. Kerena proses kehidupan manusia dalam kehidupan sehari-hari khususnya di bidang pendidikan seringkali dihadapkan kepada 
persoalan-persoalan, dimana persoalan tersebut kadang-kadang tak dapat dipecahkan oleh hanya dengan satu jawaban atau satu cara saja, akan tetapi memerlukan pengetahuan untuk kemudian disusun pemecahan yang mungkin berupa jalan alternatif terbaik. Metode diskusi ini dalam pendidikan agama Islam dapat mengembangkan kreativitas anak gemar memiliki ilmu pengetahuan, seperti sabda Rasulullah SAW.

"Dari Abdurrahman bin Abi Laili berkata: Berdiskusilah kamu, sesungguhnya berkembangnya sebuah hadits muncul dari diskusi tersebut". (HR. al-Darimi).

Oleh karena itu metode diskusi dalam pendidikan agama Islam bukanlah hanya percakapan atau debat biasa saja, tetapi diskusi timbul karena ada masalah yang memerlukan jawaban atau pendapat yang bermacam-macam. Peranan guru pendidikan agama Islam dalam metode diskusi ini sangat penting dalam rangka menghidupkan kegairahan pemikiran peserta didik mengungkapkan persoalan-persoalan pendidikan yang dihadapi.

Untuk terciptanya dikusi yang dialogis dan baik, maka guru pendidikan agama Islam hendaknya membiasakan hidup demokratis, memberikan kemerdekaan kepada setiap peserta didik untuk berpikir, serta mengemukakan pendapat secara bebas dan bertanggung jawab. Setiap perbedaan pendapat selalu dihargai sebagai sebuah keberagaman pandangan dalam melihat suatu objek kajian. Dinamika diskusi hendaknya mencerminkan sikap tenggang rasa dan saling menghormati pendapat orang lain. Guru pendidikan agama Islam hendaknya membimbing dan mengarahkan agar dinamika tersebut berjalan sesuai dengan tujuan pendidikan yang diinginkan (Nizar, 2008: 178-179).

Berdasarkan pengertian yang dikemukakan di atas terdapat beberapa komponen yang dapat digali untuk dijelaskan dan diketahui oleh seorang guru pendidikan agama Islam. Pertama, cara penguasaan bahan pelajaran. Diskusi sebagai sebuah metode dapat menghantarkan peserta didik untuk menguasai bahan pelajaran pendidikan agama Islam. Guru dan peserta didik harus sama-sama aktif mengetahui langkah-langkah metode diskusi ini agar peserta didik dapat menguasai bahan pelajaran yang disampaikan. Penekanan cara penguasaan bahan pelajaran ini adalah terletak pada peserta didik dimana mereka yang harus aktif dalam proses pelaksanaan pembelajaran sedang guru harus memberikan bimbingan dan rangsangan agar diskusi dapat berjalan baik.

Kedua, tukar menukar pendapat antar peserta didik sesuai pengalaman. Makna ini mengindikasikan terjadinya pertukaran pendapat diantara para peserta didik sesuai dengan pengetahuan yang mereka miliki. Tukar menukar pendapat merupakan bagian penting dalam proses berlangsungnya metode diskusi karena menuntut kemampuan seorang peserta didik untuk berkomunikasi dengan baik. Bertukar pendapat merupakan langkah mengungkapkan gagasan dengan bijaksana dan baik kepada peserta didik lain terkait dengan persoalan dalam pembelajaran. Proses tukar menukar pendapat menyiratkan sebuah sikap kritis dan tangguh dalam menyampaikan gagasan secara benar tapi juga tetap mengedepankan nilainilai humanis dan demokratis.

Gagasan yang diberikan saat tukar menukar pendapat harus pula didasari pada pengetahuan yang sesuai dengan 
materi saat berlangsungnya pembelajaran. Ini menggambarkan bahwa disaat peserta didik mengikuti pembelajaran dengan metode diskusi mereka harus terlebih dahulu memiliki pengetahuan dengan cara mempelajari materi yang akan didiskusikan. Semua peserta didik dituntut untuk maksimal memiliki dan mengetahui materi yang sedang dipelajari. Bila hal ini tidak dapat dimiliki oleh peserta didik maka diskusi tidak dapat berjalan dengan baik. Kredibilatas dan gengsi diskusi tidak berjalan dengan baik sesuai dengan harapan yang sesunguhnya. Oleh karena itu hal penting untuk diperhatikan adalah peserta didik harus membaca materi yang akan dipelajari setelah itu mereka harus saling memberikan komentar, pendapat, maupun tanggapan terhadap persoalan-persoalan yang muncul.

Ketiga, melalui cara demokratis dan humanis. Metode diskusi yang dilangsungkan dapat diikuti dan dilakukan oleh para peserta didik dengan cara demokratis dan humanis. Cara demokratis menggambarkan ada penghargaan dan sikap menerima pendapat yang memiliki perbedaan dengan diri peserta didik itu sendiri. Peserta didik tidak menganggap bahwa pendapatnya yang paling benar sementara pendapat lain dianggap salah. "Pembelajaran harus berlangsung dengan cara yang demokratis, partisipatif, dan humanis. Adanya suasana saling menghargai, adanya kebebasan berpendapat/berbicara, kebebasan mengungkapkan gagasan, adanya keterlibatan peserta didik dalam berbagai aktivitas di sekolah, kemampuan hidup bersama dengan teman-teman yang mempunyai pandangan berbeda".

Cara humanis menggambarkan adanya penghargaan terhadap sisi kemanusiaan di mana tidak sikap mencela dan merendahkan peserta didik lain. Oleh karena itu, paradigma pembelajaran dan pendidikan seyogianya merupakan sebuah paradigma pembelajaran yang sedari tingkat filosofis, strategi, pendekatan proses dan teknologi pembelajarannya menuju ke arah pembebasan anak didik dengan segala eksistensinya. Hal inilah kemudian baru anak didik bisa bebas mewujudkan keseluruhan potensi dirinya. Oleh karena itu pembelajaran harus memberikan peluang yang lebih luas kepada peserta didik untuk terlibat aktif dalam mengonstruksi pengetahuan dan pemahamannya bagi sebuah proses "pemanusiaannya" secara mutlak untuk ditumbuhkembangkan.

Keempat, memecahkan suatu masalah. Diskusi yang dilangsungkan bukan sekedar tukar menukar pendapat tanpa jelas arah dan tujuannya, tapi harus sampai pada proses memecahkan suatu masalah. Masalah ini dapat dikembangkan guru melalui indikator pembelajaran yang telah ditetapkan atau sering disebut tujuan pembelajaran. Penetapan sebuah masalah dapat ditentukan oleh guru dengan dua cara yaitu sebelum hari pembelajaran dan saat hari pembelajaran.

Masalah yang diberikan guru sebelum hari pembelajaran sebagai cara pertama maksudnya adalah memberikan masalah sehari atau dua hari sebelum pembelajaran itu dilangsungkan dengan menunjuk kelompok yang akan membahasnya. Di sini guru pendidikan agama Islam memberkan petunjuk pada peserta didik agar masing-masing kelompok membahas permasalahan di rumah dan telah dipersiapkan laporannya sedemikian rupa hingga pada hari pembelajaran dipresentasikan di depan kelas. Cara kedua yaitu menetapkan permasalahan pada saat hari 
pembelajaran maksudnya adalah guru memberikan permasalahan tersebut di kelas pada saat pembelajaran akan berlangsung. Di sini guru pendidikan agama Islam membagi peserta didik kepada beberapa kelompok dan menetapkan masalah masing-masing, dibahas pada saat itu juga, dan masingmasing kelompok secara bergantian mempersentasikan hasil diskusinya.

Setelah masalah ditetapkan maka masing-masing kelompok mempersentasikan hasil diskusinya dan salahsatu diantara mereka ditunjuk menjadi moderator. Sementara itu audien lainnya menyimak dan memberikan tanggapan, sanggahan, dan pertanyaan terhadap hasil presentasi kelompok tersebut. Di sinilah kemudian terjadi saling tukar menukar pendapat untuk menyelesaikan permasalahan yang sedang dibincangkan untuk mencapai kesepakatan bersama.

Kelima, di bawah bimbingan guru. Diskusi yang sedang dilangsungkan harus mendapat perhatian dan bimbingan penuh dari guru pendidikan agama Islam. Guru dalam proses diskusi tidak sekedar menjadi penonton setia akan tetapi harus memberikan bimbingan dan motivasi penuh kepada peserta didik. Bila terjadi dedlock antar peserta didik, maka guru harus menjadi penengah memberikan pendapat sebagai solusi atas persoalan yang sedang terjadi.

Keenam, untuk memperoleh keputusan bersama. Kerputusan bersama menjadi penting dalam penyelesaian sebuah persoalan yang sedang didiskusikan. Perdebatan yang terjadi melalui tukar menukar pendapat harus didasarkan untuk pencaharian sebuah keputusan yang akan dituju secara bersama-bersama.

\section{DASAR METODE DISKUSI DALAM AL- QUR'AN}

Dasar metode diskusi dalam alQur'an dapat diketengahkan dari sebuah pemikiran dan ulasan tentang pengertian metode diskusi tersebut yang menggambarkan adanya pertukaran pendapat yang menuntut penggunaan pemikiran untuk memecahkan sebuah persoalan, di mana metode diskusi dalam diskursus Indonesia dikenal dengan "metode musyawarah" dalam diskursus Islam. Musyawarah ini bila dilihat fakta-fakta sejarah memiliki kemiripan dengan makna metode diskusi dan hal itu dapat dipergunakan dalam proses pembelajaran. Metode diskusi/musyawarah ini dapat lebih jelas dilihat dalam firman Allah SWT berikut:

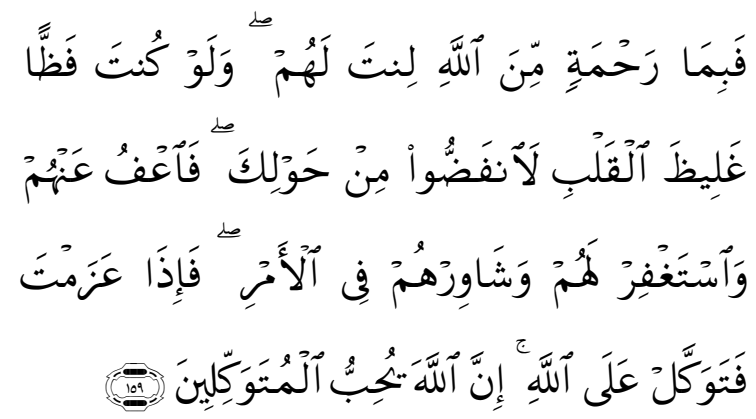

Artinya: "Maka disebabkan rahmat dari Allah-lah kamu Berlaku lemah lembut terhadap mereka. Sekiranya kamu bersikap keras lagi berhati kasar, tentulah mereka menjauhkan diri dari sekelilingmu. karena itu ma'afkanlah mereka, mohonkanlah ampun bagi mereka, dan bermusyawaratlah dengan mereka dalam urusan itu. Kemudian apabila kamu telah membulatkan tekad, Maka bertawakkallah kepada Allah. Sesungguhnya Allah menyukai orangorang yang bertawakkal kepada-Nya". (QS. Ali Imran, 3: 159).

Ayat di atas tergambar bahwa metode diskusi/musyawarah terambil dari kata "wa syawirhum" yang 
bermakna dan bermusyawarahlah dengan mereka. Ayat ini sebenarnya merupakan runtutan dari ayat-ayat sebelumnya di mana Allah SWT membimbing dan menuntun kaum muslimin secara umum, kini tuntunan diarahkan kepada Nabi Muhammad SAW, sambil menyebutkan sikap lemah lembut Nabi Muhammad SAW kepada kaum muslimin khususnya mereka yang telah melakukan kesalahan dan pelanggaran dalam perang Uhud. Sebanarnya, cukup banyak hal dalam peristiwa perang Uhud yang dapat mengundang emosi manusia untuk marah. Namun demikian, cukup banyak pula bukti yang menunjukkan kelemahlembutan Nabi Muhammad SAW. Beliau bermusyawarah dengan mereka sebelum memutuskan berperang, beliau menerima usul mayoritas mereka, walau beliau sendiri kurang berkenan; beliau tidak memaki dan mempersalahkan para pemanah yang meninggalkan markas mereka, tetapi hanya menegurnya dengan halus dan lain-lain. Jika demikian, maka disebabkan rahmat yang amat besar dari Allah, sebagaimana dipahami dari bentuk infinitif (nakirah) dari huruf $m a$ yang digunakan di sini dalam konteks penetapan rahmat-Nya-disebabkan rahmat Allah itu-engkau belaku lemah lembut terhadap mereka. Sekiranya engkau berlaku keras, buruk perangai, kasar kata lagi berhati kasar, tidak peka terhadap keadaan orang lain, tentulah mereka menjauhkan diri dari sekelilingmu, disebabkan oleh antipati terhadapmu. Karena perangaimu tidak seperti itu, maka maafkanlah kesalahankesalahan mereka yang kali ini mereka lakukan, mohonkanlah ampun kepada Allah bagi mereka, atas dosa-dosa yang mereka lakukan dan bermusyawarahlah dengan mereka dalam urusan itu, yakni dalama urusan peperangan dan urusan dunia, bukan urusan syari'at atau urusan agama. Kemudian, apabila engkau telah melakukan hal-hal di atas dan telah membulatkan tekad, melaksanakan hasil musyawarah kamu, maka laksanakan sambil bertawakallah kepada Allah. Sesungguhnya Allah menyukai orang-orang yang bertawakal kepada-Nya dan, dengan demikian, Dia akan membantu dan membimbing mereka ke arah apa yang mereka harapkan (Shihab, 2002: 310).

Metode diskusi yang tergambar dalam ayat di atas terambil dari akar kata wa syawirhum/dan bermusyawarahlah dengan mereka mengidikasikan adanya proses untuk mendiskusikan persoalan dengan siapa pun yang memiliki persoalan dengan diri kita sendiri. Hal ini berlaku juga dalam proses pembelajaran, di mana persoalan-persoalan yang ada dalam pembelajaran dapat diselesaikan dengan berdiskusi/bermusyawarah. Metode diskusi dengan demikian menuntut adanya persoalan yang akan diselesaikan dan ada orang yang akan menyelesaikan. Salah satu yang menjadi penekanan pokok dalam ayat ini menurut Quraish Shihab adalah perintah untuk melakukan musyawarah. Ini penting karena petaka yang terjadi di Uhud didahului oleh musyawarah serta sietujui oleh mayoritas. Kendati demikian, hasilnya sebagaimana yang telah diketahui, adalah kegagalan. Hasil ini boleh jadi mengantar seseorang untuk berkesimpulan bahwa musyawarah tidak perlu diadakan. Apalagi bagi Rasulullah SAW. Nah, karena itu, ayat ini dipahami sebagai pesan untuk melakukan musyawarah. Kesalahan yang dilakukan setelah musyawarah tidak sebesar kesalahan yang dilakukan tanpa musyawarah, dan kebenaran yang diraih sendirian, tidak sebaik kebenaran yang diraih bersama ((Shihab, 2002: 312). 
Kata musyawarah terambil dari akar kata syawara yang pada mulanya bermakna mengeluarkan madu dari sarang lebah. Makna ini kemudian berkembang sehingga mencakup segala sesuatu yang dapat diambil/dikeluarkan dari yang lain (termasuk pendapat). Kata musyawarah, pada dasarnya, hanya digunakan untuk hal-hal yang baik, sejalan dengan makna dasar di atas. Madu bukan saja manis, tapi ia adalah obat bagi banyak penyakit, sekaligus menjadi sumber kesehatan dan kekuatan. Itulah yang dicari di mana pun dan siapa pun yang menemukannya. Madu dihasilkan oleh lebah. Jika demikian yang bermusyarah bagaikan lebah, makhluk yang sangat disiplin, kerjasamanya mengagumkan, makanannya sari kembang, hasilnya madu, di mana pun ia hinggap tidak pernah merusak, tidak mengganggu kecuali diganggu, sengatannya pun obat. Itulah permusyawaratan dan demikian itu sifat yang melakukannya. Tidak heran jika Nabi Muhammad SAW menyamakan seorang mukmin dengan lebah (Shihab, 2002: 312).

Kata wa syawirhum/metode diskusi di atas dikaitkan dengan awal ayat di atas adalah fa bima rahmatamminallahi linta lahum/maka disebabkan rahmat Allah engkau berlaku lemah lembut terhadap mereka merupakan syarat penting bagi seorang guru yang akan menjalankan metode diskusi dalam proses pembalajarannya. Di sini tergambar adanya sifat untuk memiliki kepribadian yang mulia yang harus dimiliki oleh seorang guru dalam menggunakan metode diskusi saat proses pembelajaran, melalui harapan dan doa kepada Allah SWT agar menganugerahi. Ayat ini menjadi salah satu bukti, menurut Quraish Shihab, bahwa Allah SWT sendiri yang mendidik dan membentuk kepribadian Nabi Muhammad SAW, sebagaimana sabda beliau: "Aku dididik oleh Tuhanku, maka sungguh baik hasil pendidikan-Nya." Kepribadian beliau dibentuk sehingga bukan hanya pengetahuan yang Allah SWT limpahkan kepada beliau melalui wahyu-wahyu al-Qur'an, tetapi juga kalbu beliau disinari, bahkan totalitas wujud beliau merupakan rahmat bagi seluruh alam (Shihab, 2002: 310).

Di samping itu dapat dilihat penggalan kata pada ayat di atas yaitu, wa lau kunta fazhzhan ghalizh al-qalb lanfadhdhu min haulik/sekiranya engkau berlaku keras lagi hati kasar, tentulah mereka menajuhkan diri dari sekelilingmu, menggambarkan adanya sikap yang harus dimiliki oleh seorang guru dalam menggunakan metode diskusi dalam proses pembelajarannya. Di sini sikap yang harus dimiliki oleh seorang guru pada peserta didik saat melakukan metode diskusi adalah berlaku lemah lembut, tidak kasar, dan tidak berhati keras. Sikap ini menurut hemat penulis menjadi hal penting yang harus dimiliki oleh seorang guru dalam proses menggunakan metode diskusi, terlebih di era globalisasi sekarang ini, di mana terdapat sejumlah guru yang berlaku kurang baik terhadap peserta didik. Bila sikap ini tidak dilakukan, kemungkinan besar para peserta didik akan menjauh dari guru. Menjauh dalam makna bahwa akan sulit bagi peserta didik untuk memahami materi pembalajaran yang diajarkan guru dengan metode diskusi, dan para peserta didik akan merasa kesulitan untuk menerima materi pembelajaran karena guru saat pembelajaran berlaku kasar dan berhati keras. Menurut Quraish Shihab, seseorang yang melakukan musyawarah/diskusi, apalagi berada dalam posisi pemimpin, yang pertama ia harus hindari ialah tutur kata yang kasar serta sikap keras kepala, karena, jika tidak, mitra musyawarah akan bertebaran pergi 
(Shihab, 2002: 313). Petunjuk ini dikandung oleh penggalan awal ayat di atas sampai firman-Nya: wa lau kunta fazhzhan ghalizh al-qalb lanfadhdhu min haulik.

Dalam menggunakan metode dikusi tersebut, seorang guru harus memiliki sikap memberi maaf dan membuka lembaran baru dan juga menyebarkan sikap itu pada peserta didik. Seluruh peserta diskusi dalam proses pembalajaran diharuskan memiliki sikap memberi maaf dan membuka lembaran baru. Petunjuk ini terlihat dari penggalan ayat di atas $f a^{\prime} f u$ 'anhum/karena itu maafkanlah mereka. Kata ini yang terinti adalah "maaf", menurut Quraish Shihab, secara harfiah berarti menghapus. Memaafkan adalah menghapus bekas luka hati akibat perlakuan pihak lain yang dinilai tidak wajar. Ini perlu karena tiada musyawarah tanpa ada pihak lain, sedangkan kecerahan pikiran hanya hadir bersamaan dengan sirnanya kekeruhan hati (Shihab, 2002: 313). Hal ini semakin jelas bahwa memang dalam proses berdiskusi kemungkinan terjadi keberlainan pendapat tentang suatu persoalan dan kepribadian peserta didik yang berbeda di mana tidak mungkin satu pendapat semua peserta didik, diperlukan adanya sikap saling membuka hati dan maaf ada di setiap diri peserta diskusi.

Dapat diungkapan pula dari isi ayat di atas mendorong kita sebagai guru dan juga para peserta didik yang belajar dengan menggunakan metode diskusi/musyawarah, dimana setelah selesai berdiskusi/bermusyawarah haruslah berserah diri pada Allah SWT. Hal ini dapat dilihat di penghujung ayat di atas, fa idza 'azamta fa tawakkal 'ala Allah, apabila telah selesai berdiskusi dalam proses pembelajaran maka dianjurkan untuk menyerahkan semua proses dan hasil diskusi dalam pembelajaran. Di sini merupakan akhir yang sangat penting dalam proses pengembangan diri peserta didik dan guru dalam menggunakan metode diskusi, karena harus berserah diri pada Sang Pencipta Allah SWT setiap akhir proses pembelajaran. Di sini ada hal penting untuk dimiliki oleh peserta didik dan guru bahwa apa pun yang dihasilkan oleh peserta didik dan guru saat proses berdikusi haruslah dalam rangka untuk mengagungkan Allah SWT.

Ayat di atas juga mengilustrasikan adanya lapangan diskusi, yaitu fi al-amr yang diterjemahkan di atas dengan dalam urusan itu. Dari segi konteks ayat ini, dipahami bahwa urusan dimaksud adalah urusan peperangan. Karena itu, ada ulama yang membatasi musyawarah yang diperintahkan kepada Nabi Muhammad SAW terbatas dalam urusan tersebut. Menurut Quraish Shihab, pandangan ini tidak didukung oleh praktik Nabi Muhammad SAW, bahkan tidak sejalan dengan sekian ayat alQur'an.

Dari al-Qur'an, ditemukan dua ayat lain yang menggunakan akar kata musywarah, yang dapat diungkap di sini guna memahami lapangan musyawarah. Pertama, QS. Al-Baqarah 2:223, di mana ayat ini membicarakan bagaimana seharusnya hubungan suami-istri dalam mengambil keputusan yang berkaitan dengan rumah tangga dan anak-anak, seperti soal menyapih anak. Di sana Allah memberikan petunjuk agar persoalan itu (dan juga persoalanpersoalan rumah tangga lainnya) dimusyawarahkan/didiskusikan antara suami istri. Ayat kedua, adalah QS. asySyura, 42:38, yang menjanjikan bagi orang-orang mukmin ganjaran yang lebih baik dan kekal di sisi Allah SWT. Orang-orang mukmin dimaksudkan memiliki sifat-sifat, antara lain adalah amruhum syura bainahum/urusan 
mereka diputuskan dengan musyawarah antar mereka (Shihab, 2002: 314-315).

Dalam soal amr atau urusan, dari alQur'an ditemukan adanya urusan yang hanya menjadi wewenang Allah SWT semata-mata, bukan wewenang manusia betapa pun agungnya. Ini antara lain, terlihat dalam jawaban Allah SWT tentang ruh (baca QS. al-Isra', 17:85) datangnya Kiamat (QS. an-Nazi'at, 79:42). Demikian juga soal taubat (baca QS. Ali Imran 3:128) serta ketentuan syari'at agama (QS. al-An'am, 6:57) dan lain-lain (Shihab, 2002: 315). Dalam konteks ketetapan Allah dan ketetapan Rasulullah SAW yang bersumber dari wahyu, secara tegas al-Qur'an menyatakan bahwa: "Tidaklah patut bagi laki-laki yang mukmin dan tidak (pula) bagi perempuan yang mukmin, apabila Allah dan Rasul-Nya telah menetapkan suatu ketetapan, akan ada bagi mereka pilihan (yang lain) tentang urusan mereka. Dan barang siapa mendurhakai Allah dan Rasul-Nya maka sungguh, dia telah sesat, sesat yang nyata" (QS. al-Ahzab, 33:36).

Di sini dapat tergambarkan bahwa persoalan-persoalan yang telah ada petunjuknya dari Allah SWT secara tegas dan jelas, baik langsung maupun melalui Rasulullah SAW, persoalan itu tidak lagi termasuk yang dapat dimusyawarahkan. Musyawarah hanya dilakukan dalam hal-hal yang belum ditentukan petunjuknya serta soal-soal kehidupan duniawi, baik yang petunjuknya bersifat global maupun yang tanpa petunjuk dan yang mengalami perubahan. Dengan demikian, menurut Quraish Shihab, Nabi Muhammad SAW bermusyawarah dalam urusan masyarakat, bahkan beliau dalam beberapa hal bermusyawarah dan menerima saran menyangkut beberapa urusan keluarga beliau atau pribadi beliau. Salah satu kasus keluarga yang beliau mintakan saran adalah kasus rumor yang menimpa istri beliau, 'Aisyah r.a. dan pada akhirnya turun ayat yang menampik segala rumor itu (Shihab, 2002: 316).

Hal di atas itulah yang menjadi materi penting yang dapat didiskusikan dalam proses pembelajaran. Materi ini penting untuk dikemukakan karena terkadang dijumpai sejumlah orang berdiskusi sampai persoalan-persoalan yang memang sudah jelas jawaban dan ketetapannya dalam al-Qur'an. Maka dalam proses berdikusi dibutuhkan orang-orang yang memiliki kecapakan dan memiliki sifat percaya agar proses dan hasil diskusi tersebut dapat mencapai hal yang maksimal. Oleh karena itu, sebagai seorang calon guru atau guru PAI hari ini dibutuhkan kemampuan untuk menjalankan metode diskusi tersebut dengan baik dalam proses pembelajarannya.

\section{KONDISI PENGGUNAAN METODE DISKUSI}

Metode diskusi ini sering digunakan Rasulullah Muhammad SAW bersama para sahabat terutama untuk mencari kata sepakat. Al-Mubarakfury menyebutkan, sebagai dikutip oleh Nawwal al-Thuwairaqi, dalam Samsul Nizar dan Zainal Efendi Hasibuan, bahwa pada perang Badar kaum muslimin berhasil menawan 70 orang yang diikat dengan tali. Rasulullah SAW membagikan mereka sebagai tawanan kepada para sahabat dan beliau berwasiat untuk berlaku baik kepada mereka (Nizar \& Hasibuan, 2011: 61). Ketika Rasulullah SAW tiba di Madinah, beliau mengadakan musyawarah dengan para sahabatnya mengenai tindakan apa yang harus diperlakukan kepada para tawanan. Abu Bakar al-Shiddiq mengusulkan mereka diberi kesempatan untuk menebus dirinya untuk menjadi sumber kekuatan bagi umat Islam. Umar berpendapat agar mereka 
dibunuh, Rasulullah SAW menerima pendapat Abu Bakar al-Shiddiq (Nizar \& Hasibuan, 2011: 61).

Berdasarkan ulasan yang telah dikemukakan sebelumnya dapat diketengahkan pula di sini bahwa metode dikusi tersebut sangat tepat digunakan untuk beberapa hal berikut: Pertama, saat guru PAI akan mengajarkan materi pembelajaran yang mengandung persoalan yang memungkinkan untuk diberikan kajian mendalam. Materi pembelajaran yang mengandung persoalan mungkin untuk dijadikan kajian merupakan materi yang sifatnya terbuka di mana para peserta didik memiliki ruang untuk mendiskusikannya. Di sini penekanannaya pada materi yang memiliki sifat keterbukaan di mana memungkinkan untuk dapat dianalisis secara terbuka dari berbagai aspek. Materi pembelajaran yang dapat memberi ruang bagi peserta didik untuk mengkritisi dan dapat diperdebatkan dari berbagai segi dan aspeknya.

Maka, guru PAI dituntut untuk menganalisis berbagai materi yang ada dalam pembelajaran PAI, mana yang dapat didiskusikan dan mana yang tidak. Hal ini dianggap penting, agar guru tidak salah dalam memilih materi yang akan diajarkan pada peserta didik dengan menggunakan metode diskusi. Tidaklah memungkinkan bagi guru PAI menggunakan metode diskusi tanpa melakukan analisis terlebih dahulu terhadap materi yang akan diajarkan. Sebab, ketidaktepatan dalam memilih materi yang akan didiskusikan dapat berakibat bagi kekurangtepatan antara metode yang dipilih dengan motivasi belajar peserta didik dan minat peserta didik dalam belajar.

Kedua, materi yang berkaitan dengan persoalan-persoalan duniawi yang belum ditentukan petunjuknya di dalam alQur'an dan Sunnah Rasul SAW. Di sini dapat tergambarkan seperti yang telah disebutkan di atas, bahwa persoalanpersoalan yang telah ada petunjuknya dari Allah SWT secara tegas dan jelas, baik langsung maupun melalui Rasulullah SAW, persoalan itu tidak lagi termasuk yang dapat dimusyawarahkan. Musyawarah hanya dilakukan dalam hal-hal yang belum ditentukan petunjuknya serta soal-soal kehidupan duniawi, baik yang petunjuknya bersifat global maupun yang tanpa petunjuk dan yang mengalami perubahan. Dengan demikian, menurut Quraish Shihab, Nabi Muhammad SAW bermusyawarah dalam urusan masyarakat, bahkan beliau dalam beberapa hal bermusyawarah dan menerima saran menyangkut beberapa urusan keluarga beliau atau pribadi beliau. Salah satu kasus keluarga yang beliau mintakan saran adalah kasus rumor yang menimpa istri beliau, 'Aisyah r.a. dan pada akhirnya turun ayat yang menampik segala rumor itu (Shihab, 2002: 316).

Maka, seorang guru PAI dituntut untuk memperhatikan hal di atas yang menjadi materi penting untuk didiskusikan dalam proses pembelajaran di kelas. Materi ini penting untuk dikemukakan karena terkadang dijumpai sejumlah orang berdiskusi sampai persoalan-persoalan yang memang sudah jelas jawaban dan ketetapannya dalam al-Qur'an. Maka dalam proses berdikusi dibutuhkan orang-orang yang memiliki kecapakan dan memiliki sifat percaya agar proses dan hasil diskusi tersebut dapat mencapai hal yang maksimal.

Ketiga, metode diskusi tepat digunakan apabila para peserta didik memiliki kecakapan dan sifat percaya diri dalam proses pembelajaran terkait dengan materi yang akan diajarkan. Penekanan di sini adalah di mana para peserta didik memiliki kecakapan materi dan kepercayaan diri dalam mengkomunikasikan pemikirannya pada khalayak ramai. Hal ini pulalah yang menjadi bagian penting, adanya 
kecakapan kepercayaan diri berkomunikasi pada diri peserta didik, mengapa metode diskusi ini dapat dipergunakan dalam proses pembelajaran.

Maka, perlu sekali bagi Anda sebagai guru PAI atau calon guru PAI untuk memperhatikan kemampuan diri individu para peserta didik. Perhatian guru PAI tersebut haruslah tertuju pada kepercayaan diri para peserta didik, kemampuan kepercayaan diri dalam berkomunikasi, kecakapan penguasaan materi yang dimiliki oleh peserta didik, dan berbagai bentuk sikap lainnya yang mendukung untuk dijalankannya metode diskusi dalam pembelajaran PAI. Tentu semua itu membutuhkan pengetahuan guru PAI tentang berbagai ilmu yang melingkupinya seperti, psikologi perkembangan, psikologi pendidikan, psikologi agama, dan lainnya.

\section{KELEBIHAN DAN KEKURANGAN METODE DISKUSI \\ Kelebihan Metode Diskusi}

Ada beberapa kelebihan metode diskusi dalam pembelajaran PAI, antara lain: Pertama, dapat memperluas wawasan peserta didik. Wawasan peserta didikan dapat berkembang melalui metode diskusi yang dipergunakan oleh guru pendidikan agama Islam dalam proses pembelajaran pendidikan agama Islam di kelas. Wawasan luas sangat urgen bagi proses perkembangan intelektualitas dan pola pikir peserta didik dalam mengikuti pembelajaran pendidikan agama Islam. Wawasan luas ini dapat menjadikan pemikiran dan diri peserta didik untuk terus belajar karena akan menambah ilmu dan memandang sebuah persoalan tidak hanya dari satu aspek saja, akan tetapi dari berbagai segi dan aspeknya. Hal ini kemudian akan memunculkan peserta didik menjadi peserta didik Islam yang berfikir inklusif dalam makna berfikir luas dan tidak cepat menyalahkan orang lain.

Dalam pelajaran pendidikan agama Islam, hal ini dapat dilihat misalnya ketika berbicara tentang persoalan qunut yang sudah memang diperdebatkan dari awal. Bila peserta didik tidak punya wawasan yang luas maka mereka akan cenderung ta'assub mazhab yang hanya memikirkan pendapatnya yang paling benar. Mengapa demikian, karena wawasan sempit dan hanya mengetahui satu dasar hukum saja. Sementara wawasan luas itu akan memunculkan berbagai dasar ilmu pengetahun terkait dengan persoalan tadi. Bila demikian halnya maka peserta didik yang memiliki wawasan luas akan cenderung lebih demokratis, toleran, dan humanis.

Di sinilah dampak positif dari penggunaan metode diskusi yang dilakukan oleh seorang guru pendidikan agama Islam dalam proses pembelajarannya. Peserta didik akan belajar terus-menerus agar memiliki wawasan keilmuan yang luas tentang materi pendidikan agama Islam yang diajarkan. Adanya keinginan untuk belajar secara kontiniu dalam kehidupan peserta didik akan membawa dampak positif lahirnya karya-karya akademik yang dapat memberikan kontribusi penting bagi perkembangan ilmu pengetahuan.

Kedua, merangsang kreativitas peserta didik dalam memunculkan ide dalam memecahkan suatu masalah. Metode diskusi dalam pendidikan agama Islam dapat merangsang kreativitas peserta didik secara simultan melalui pemunculan ide-ide dalam memecahkan sebuah persoalan. Diskusi yang berlangsung menjadikan masingmasing peserta didik berfikir secara individu untuk memberikan jawaban 
dan solusi terhadap persoalan yang berkembang atau diajukan oleh temanteman lainnya. Tidak hanya itu kreativitas itu mencul pula melalui pemberian tanggapan terhadap komentar-komentar yang dilontarkan oleh audiens atau peserta diskusi.

Maka, bila dalam sebuah kelas pengajaran pendidikan agama Islam ada peserta didik yang diam akan tergugah hatinya untuk memberikan sumbangan pemikiran atas persoalan yang berkembang dalam pembelajaran dalam metode diskusi tersebut. Dorongan kreativitas itu muncul melihat temanteman peserta didik masing-masing memberkan komentar. Biasanya pengaruh lingkungan itu sangat besar bagi proses perkembangan manusia apalagi peserta didik ke depan. Kelas yang «hidup» dengan suasana diskusinya akan berdampak bagi kreativitas untuk berbicara melalui bertanya dan memberikan komentar terhadap sebuah permasalahan yang muncul dalam diskusi.

Ketiga, dapat mengembangkan sikap menghargai pendapat orang lain. Penggunaan metode diskusi yang diterapkan oleh guru pendidikan agama Islam sangat baik untuk perkembangan kepribadian peserta didik khusus dalam proses menghargai pendapat orang lain. Sikap menghargai pendapat ini sangat baik dikembangkan dalam dunia modern sekarang. Salah satu kecenderungan bahkan kebiasaan orang beriman adalah selalu ingin berbuat baik kepada orang lain, baik memiliki hubungan kekerabatan atau tidak, yang dikenal maupun tidak dikenal. Orang beriman selalu ingin berbuat baik, karena itu merupakan salah satu cara dalam bersyukur kepada Allah SWT atas kebaikan-kebaikan yang diberikan kepadanya, seperti firman-Nya:

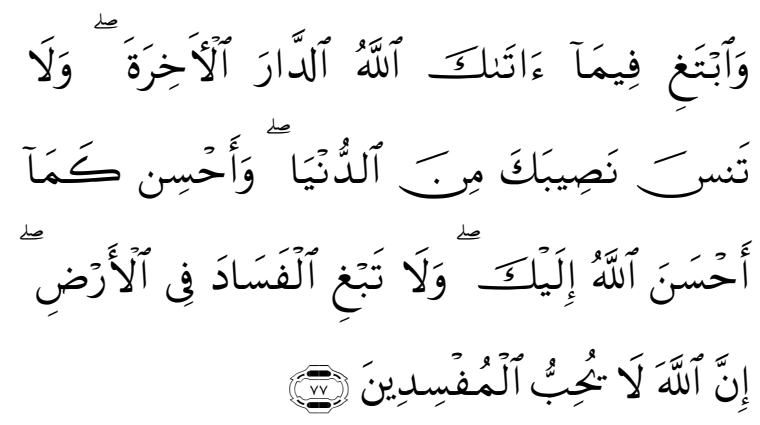

Artinya: "Dan carilah pada apa yang telah dianugerahkan Allah kepadamu (kebahagiaan) negeri akhirat, dan janganlah kamu melupakan bahagianmu dari (kenikmatan) duniawi dan berbuat baiklah (kepada orang lain) sebagaimana Allah telah berbuat baik, kepadamu, dan janganlah kamu berbuat kerusakan di (muka) bumi. Sesungguhnya Allah tidak menyukai orang-orang yang berbuat kerusakan". (QS. Al-Qashash, 28:77).

Kecenderungan manusia secara alamiah adalah keinginan untuk mendapat tanggapan atau penghargaan atas apa yang dilakukannya. Kebutuhan untuk menuangkan ekspresi diri secara positif telah mendorong setiap orang untuk terus menghasilkan karya terbaik demi kebaikan dirinya dan orang lain. Oleh karena itu, upaya dan hasil karya kreatif yang berguna bagi kemaslahatan orang banyak sudah selayaknya memperoleh penghargaan yang positif pula.

Islam sangat menganjurkan umatnya agar saling menghargai satu sama lain. Sikap menghargai terhadap orang lain tentu didasari oleh jiwa yang santun yang dapat menumbuhkan sikap menghargai orang di luar dirinya. Kemampuan tersebut harus dilatih lebih dahulu untuk mendidik jiwa manusia sehingga mampu bersikap penyantun. Seperti contoh, ketika bersama-sama menghadapi persoalan tertentu, seseorang harus berusaha saling memberi dan menerima saran, pendapat, atau nasihat dari orang lain yang pada awalnya pasti akan terasa 
sulit. Sikap dan perilaku ini akan terwujud bila pribadi seseorang telah mampu menekan ego pribadinya melalui pembiasaan dan pengasahan rasa empati melalui pendidikan akhlak.

Keempat, dapat menumbuhkan partisipasi peserta didik menjadi lebih aktif. Partisipasi pembalajaran peserta didik terkadang sangatlah rendah dalam mengikuti pembelajaran. Munculnya penggunaan metode diskusi yang maksimal dapat membuat peserta didik aktif dan partisipatif dalam kegiatan pembelajaran. Partisipasi peserta didik sangat penting ditumbuhkan pada setiap individu, karena hal itu menjadi bagian untuk menjadi muslim yang bermanfaat bagi orang lain. Dengan adanya metode diskusi/musyawarah tersebut mendorong peserta didik untuk memiliki partisipasi dalam setiap pembicaraan, dan ini merupakan bagian dari tugas seorang muslim dalam kehidupan.

Suasana seperti di atas, di mana peserta didik berpartisipasi aktif dalam pembelajaran, akan menghartankan mereka menjadi muslim yang baik yang bermanfaat bagi yang lain. Tumbuhnya partisipasi akan membawa peserta didik bahwa mereka harus dapat memberikan kontribusi bagi peserta didik yang lain. Peserta didik akan merasa bahwa kehadiran diri masing-masing mereka harus memberikan manfaat bagi peserta didik lainnya. Demikian juga sebaliknya bahwa peserta didik yang lainnya merasakan hal yang sama harus dapat memberikan partisipasi yang sama. Hal ini pada akhirnya semua peserta didik memiliki sikap yang sama hingga semua merasa akan penting peran masingmasing dalam membangun pembelajaran yang berkualitas.

Kelima, merangsang peserta didik berfikir dan mengeluarkan pendapat sendiri. Zakiah Daradjat, et. al., mengatakan bahwa metode diskusi sangat efektif untuk merangsang peserta didik berpikir dan mengeluarkan pendapat sendiri. Metode ini juga penting karena dengan menyelesaikan suatu problematika tidak hanya cukup dengan satu jawaban saja, tetapi membutuhkan beberapa jawaban saja, tetapi membutuhkan beberapa jawaban sebelum memilih alternatif jawaban terbaik (Daradjat, 2001, 292).

Berpikir dan mengeluarkan pendapat sendiri tanpa ada yang memberi tahu atau berbeda dengan pendapat yang lain merupakan hal positif untuk membangun persepsi sendiri dan kemandirian akademik. Metode diskusi mendorong peserta didik untuk memiliki pemikiran sendiri yang harus berbeda dengan pendapat lainnya dari sudut pandang yang berbeda. Apabila bila hanya sama pendapatnya dengan peserta didik lain, hal itu bukanlah kebaikan dan keunggulan yang baik dalam berdiskusi, dan bahkan suasana diskusi pun tidak menarik dan berkualitas. Maka dengan demikian akan lahirlah apa yang disebut di atas dengan sikap kemandirian akademik. Sikap kemandirian akademik akan lahir dari adanya proses untuk berpikir dan mengeluarkan pendapat sendiri. Dan, metode diskusi dapat mendorong untuk lahirnya sikap kemandirian akademik itu sendiri.

\section{Kelemahan Metode Diskusi}

Selain memiliki banyak kelebihan, metode diskusi dalam pembelajaran PAI juga memiliki kelemahan, antara lain: Pertama, kemungkin besar diskusi akan dikuasai oleh peserta didik yang suka berbicara atau ingin menonjolkan diri. Peserta didik yang memiliki kemampuan berbicara dan pemberani akan lebih menguasai pembelajaran di banding dengan peserta didik yang diam. Hal ini terjadi karena peserta didik yang kurang berani berbicara akan 
merasa malu dan tidak mampu berkompetisi dalam diskusi. Diskusi sarat dengan proses penguasaan terhadap situasi dan kondisi diskusi, maka peserta didik yang miliki keberanian diri, akan lebih menguasai kelas atau proses diskusi di banding mereka yang tipe pendiam yang tidak suka untuk menonjolkan diri.

Kedua, tidak dapat dipakai pada kelompok yang besar. Metode diskusi akan tidak efektif bila dipergunakan pada kelompok yang sangat besar karena kurang dapat dikuasai suasana. Diskusi yang menuntut pada konsentrasi dalam proses pembahasannya tidak dimungkinkan dipergunakan bagi kelompok yang besar karena hal itu menjadi kurang efektif. Dikatakan kurang efektif untuk kelompok besar karena bisa saja hal organ-organ atau orang-orang yang ada di kelompok itu tidak terlibat secara maksimal dalam proses pembahasan materi yang diberikan.

Di samping itu kelompok besar tersebut kurang dikuasai suasana pembelajaran yang memungkinkan guru kesulitan menguasai kelas. Suasana pembelajaran yang kondusif saat melaksanakan metode diskusi sangatlah dibutuhkan untuk keberhasilan pembelajara. Ketidakefektifan tersebut menjadi pengganggu untuk keberhasilan metode diskusi dalam proses pembelajaran. Kelompok yang besar tersebut dalam proses metode diskusi tidak dapat efektif dipergunakan karena memang suasana kelas akan sulit dikendalikan dengan baik oleh guru PAI.

Ketiga, peserta mendapat informasi yang terbatas. Metode diskusi yang dipergunakan dalam pembelajaran PAI akan membuat informasi hanya terbatas sesuai dengan tema diskusi. Ya, hal ini bisa saja dijadikan salah satu yang menjadi kelemahan dari metode diskusi walau sesungguhnya masih dapat diperdebatkan. Bisa saja dalam proses berdiskusi para peserta didik akan mendapat informasi yang terbatas, karena para peserta didik yang mengikuti peserta diskusi terbatas pengetahuan mereka. Bila hal ini yang terjadi maka informasi yang akan diterima oleh peserta didik akan menjadi terbatas. Apabila peserta diskusi kurang menguasai materi dan analisis juga yang kurang, maka informasi yang dapat diambil atau diterima oleh peserta didik lain akan terbatas.

Keempat, menyerap waktu yang cukup banyak. Proses penggunaan metode diskusi dalam pembelajaran PAI akan menyerap waktu yang banyak karena persoalan dapat berkembang. Penggunaan metode diskusi dalam pembelajaran menyerap banyak waktu, karena, para peserta didik yang memberikan komentar dalam berdiskusi terkadang tak terkontrol dengan efisien hingga berbicara dalam jangka waktu yang panjang. Akibatnya, waktu pun akan menjadi korban dan semakin mengganggu waktu orang lain untuk memberikan komoentar. Apabila guru tidak jeli dengan persoalan penggunaan waktu, maka akan berakibat fatal pada materi-materi berikutnya yang harus diselesaikan dalam proses pembalajaran.

Kelima, tidak semua guru memahami cara peserta didik melakukan diskusi. Pemahaman guru PAI terhadap peserta didik terkait karakteristik mereka dapat mengganggu jalannya diskusi. Persoalan pemahaman peserta didik sesungguhnya tidaklah menjadi hal yang krusial, manakala peserta didik mau memahami proses dan jalannya diskusi serta memperhatikan kondisi peserta didik. Hanya saja persoalan ini agak sering terabaikan oleh para guru dalam proses pembelajaran. Setelah mereka memasukkan anaknya ke sekolah para 
orang tua menganggap sekolah, melalui para guru, dapat menyelesaikan persoalan pendidikan anaknya. Metode diskusi akan kurang baik dipergunakan manakala karakter peserta didik atau berbagai pola-pola prilaku mereka tidak sesuai untuk melaksanakan diskusi.

\section{DESAIN METODE DISKUSI}

Untuk melaksanakan kegiatan proses belajar mengajar pendidikan agama Islam dengan menggunakan metode diskusi, guru pendidikan agama Islam harus memberikan pertolongan berupa penyajian problema sebagai perangsang, bimbingan dan pengarahan di dalam proses belajar tersebut. Ada tujuh siklus desain metode diskusi sebagai panduan bagi guru pendidikan agama Islam dalam menjalankan metode diskusi pada setiap pembelajaran PAI yang dilangsungkan, yaitu: Pertama, merumuskan tujuan pembelajaran dengan menggunakan metode diskusi. Tujuan pembelajaran ini sering juga disebut merumuskan tujuan diskusi dan dapat diperhatikan oleh guru pendidikan agama Islam dalam standar kompetensi, kompetensi dasar dan terkhusus dalam indikator pembelajaran. Indikator pembelajaran inilah yang menjadi perhatian penting guru pendidikan agama Islam untuk menentukan apakah metode diskusi itu layak dipergunakan atau tidak.

Teknik yang dapat dipergunakan guru PAI dalam hal ini adalah: (1) Menanyakan kepada peserta didik pembelajaran yang telah lalu; (2) Menyampaikan secara gamblang tujuan pembelajaran dengan metode diskusi tersebut; (3) Menyampaikan arti dan manfaat tujuan pembelajaran tersebut bagi peserta didik; dan (4) Menyampaikan fungsi dan manfaat dari tujuan pembelajaran tersebut bagi perkembangan ilmu pengetahuan dan bagi kemajuan umat manusia. Teknikteknik ini harus diperhatikan oleh guru Anda sebagai guru PAI atau sebagai calon guru PAI agar metode diskusi yang dipergunakan dapat berjalan dengan baik dan maksimal.

Kedua, menentukan mekanisme dan tata tertib diskusi. Langkah ini sangatlah penting diperhatikan guru pendidikan agama Islam bila ingin sukses dalam menggunakan metode diskusi. Mekanisme dan tata tertib diskusi harus ditentukan pada awal pembelajaran agar proses pembelajaran pendidikan agama Islam dapat berlangsung dengan tertib dan nyaman hingga tujuan pembelajaran dapat tercapai.

Di sini guru pendidikan agama Islam harus membuat mekanisme dan tata tertib metode diskusi secara tertulis ataupun lisan. Tertulis dimaksudkan agar semua peserta didik dapat membaca dan memegang aturan tersebut sekaligus sebagai alat kontrol bagi peserta lain dalam berdiskusi. Aturan tertulis ini juga dapat membantu guru pendidikan agama Islam dalam berlangsungnya proses pembelajaran dimana peserta didik lain dapat mengingatkan bila ada yang menyimpang dari alur. Di samping itu dapat juga diberkan aturan secara lisan bila memang hal itu sudah dapat dipatuhi dengan konsekuen oleh para peserta didik sebagai peserta diskusi.

Pada siklus ini sebagai seorang calon guru PAI atau seorang guru pendidikan agama Islam harus melakukan hal-hal sebagai berikut; (1) Menentukan format susunan tempat peserta didik dalam berdikusi; (2) Menyampaikan tata tertib untuk berjalannya proses diskusi pada peserta didik sebagai peserta pembelajaran; (3) Membentuk dan menentukan jumlah kelompok diskusi berikut peserta didik sebagai anggota kelompoknya; (4) Meminta pada semua peserta diskusi untuk mematuhi tata 
tertib dengan baik saat proses berdiskusi berlangsung; (5) Meminta pada semua peeserta diskusi agar menjaga harmonisasi dan kebermaknaan akademik di antara para peserta diskusi agar dapat menghasilkan pembelajraran yang berkualitas dan bermakna.

Ketiga, merumuskan masalah atau topik yang akan didiskusikan. Untuk keberhasilan diskusi, maka masalah atau topik yang harus mempermasalahkan topik-topik yang memang memerlukan pemikiran diskusi antara pihak-pihak yang terlibat. Topik diskusi hendaknya merupakan hal-hal yang menarik minat dan perhatian peserta didik atau urgen. Peserta didik akan memiliki motivasi yang kuat dalam memecahkan soal, kalau mereka berminat dan menaruh perhatian terhadap masalah itu. Masalah itu harus mengundang banyak kemungkinan jawaban, dan masing-masing jawaban harus dapat dijamin kebenarannya. Di samping itu masalah atau topik harus merangsang pertimbangan, kemampuan berpikir logis dan usaha memperbandingkan. Jadi tidak sembarang masalah dapat dijadikan sebagai bahan diskusi. Di sinilah diperlukan kecermatan guru pendidikan agama Islam sebagai penanggung jawab diskusi dalam memilih mana masalah yang perlu diselesaikan.

Pada siklus ini Anda sebagai seorang calon guru PAI atau juga seorang guru pendidikan agama Islam harus melakukan hal-hal sebagai berikut; (1) menentukan dan merumuskan aspekaspek masalah yang akan didiskusikan; (2) Membagi permasalahan atau topiktopik tersebut sesuai dengan jumlah kelompok yang ada dalam pembelajaran saat itu; (3) Meminta para peserta didik sesuai dengan kelompok masing-masing memahami masalah yang telah diberikan oleh guru pada mereka; (4)
Guru PAI mengarahkan agar semua peserta didik dalam kelompok masingmasing dapat menerima permasalahan yang diberikan dan bersedia untuk membahasnya dengan baik di dalam kelompok masing-masing.

Keempat, mengatur kelompokkelompok diskusi. Kelompok diskusi dalam pembelajaran dengan metode diskusi menjadi nilai pembeda dengan yang lainnya dan hal ini harus diperhatikan dan diatur oleh guru PAI. Mengatur kelompok-kelompok diskusi dilakukan setelah masalah atau topik yang akan dibahas telah dibagikan. Maka diperlukan pengaturan kelompok dan hal itu menuntut untuk diperhatikan secara intensif disusun dengan baik. Guru PAI harus secara detail menentukan siapa saja yang akan menempati suatu kelompok dan kelompok lainnya. Pengaturan kelompok diskusi ini menjadi bagian penting dalam mensukseskan penggunaan metode diskusi tersebut dalam pembelajaran PAI. Pada siklus ini, seorang guru PAI atau calon guru PAI menentukan kelompok diskusi dan mengatur tempat duduknya dengan baik agar pembelajaran dapat berjalan dengan teratur dan tertib.

Pada langkah ini, Anda sebagai calon guru PAI atau juga seorang guru guru PAI dapat melakukan teknik-teknik berikut: (1) Dengan pimpinan guru PAI, para peserta didik bergabung sesuai dengan anggota kelompok diskusi masing-masing sesuai dengan yang telah ditentukan; (2) Guru PAI meminta setiap kelompok memilih pimpinan diskusi (ketua, sekretaris, pelapor). Tugas pimpinan diskusi adalah mengatur dan mengarahkan diskusi serta mengatur "lalu lintas" pembicaraan; (3) Guru PAI mengatur tempat duduk, ruangan, sarana, dan sebagainya sesuai dengan tujuan diskusi; (4) Guru PAI meminta pada semua peserta diskusi dalam 
kelompok agar berpartisipasi aktif dalam memberikan kontribusi untuk menyelesaikan masalah yang telah diberikan.

Kelima, melaksanakan diskusi. Setiap anggota diskusi hendaknya tahu persis apa yang akan didiskusikan dan bagaimana cara berdiskusi. Diskusi harus berjalan dalam suasana bebas, setiap anggota tahu bahwa mereka mempunyai hak bicara yang sama. Pada siklus ini, seorang guru pendidikan agama Islam memiliki peran penting dalam proses berlangsungnya pembelajaran dengan metode diskusi. Sebagai pemimpin diskusi, guru pendidikan agama Islam berperan untuk mempertahankan kelangsungan, kelancaran dan efektivitas diskusi, dan guru pendidikan agama Islam sebagai pemimpin diskusi memegang peranan menentukan.

Menurut Dimyati dan Mudjiono (2003: 125),Terdapat sejumlah peranan yang harus dimainkan guru sebagai pemimpin diskusi antara lain: (1) initiating, yakni menyarankan gagasan baru, atau cara baru dalam melihat masalah yang sedang didiskusikan; (2) seeking information, yakni meminta fakta yang relavan atau informasi yang otoritarif tentang topik diskusi; (3) giving information, yakni fakta yang relavan atau menghubungkan pokok diskusi dengan pengalaman pribadi peserta; (4) giving opinion, yakni memberi pendapat tentang pokok yang sedang dipertimbangkan kelompok, bisa dalam bentuk menantang konsesus atau sikap "menerima" kelompok; (5) clarifying, yakni merumuskan kembali pernyataan sesorang dan memperjelas pernyataan seseorang anggota; (6) elaborating, yakni mengembangkan pernyataan seseorang atau memberi contoh atau penerapan; (7) controlling, yakni menyakinkan bahwa giliran bicara merata; dan menyakinkan bahwa anggota yang perlu bicara, memperoleh giliran bicara; (8) encouraging, yakni bersikap resetif dan responsitif terhadap pernyataan serta buah pikiran anggota; (9) setting standards, yakni memberi atau meminta kelompok menetapkan kriteria untuk menilai urunan anggota; (10) harmonizing, yakni menurunkan kadar ketegangan yang terjadi dalam diskusi; (11) relieving tension, yakni melakukan penyembuhan setelah terjadinya tegangan; (12) coordinating, yakni menyimpulkan gagasan pokok yang timbul dalam diskusi, membantu kelompok mengembangkan gagasan; (13) orientating, yakni menyampaikan posisi yang telah dicapai kelompok dalam diskusi dan mengarahkan perjalanan diskusi selanjutnya; (14) testing, yakni menilai pendapat dan meluruskan pendapat ke arah yang seharusnya dicapai; (15) consensus testing, menilai tingkat kesepakatan yang telah dicapai dan menghindarkan perbedaan pandangan; dan (16) summarizing, yakni merangkum kesepakatan yang telah dicapai.

Berdasarkan pendapat di atas dapat diketahui hal-hal penting yang dimainkan oleh guru dalam proses diskusi. Hanya saja yang perlu dikritisi adalah bahwa yang menjadi pemimpin diskusi tidak hanya guru saja akan tetapi peserta didik yang dianggap mampu juga dapat dijadikan sebagai pemimpin diskusi. Pada saat peserta didik menjadi pemimpin diskusi, guru pendidikan agama Islam dapat menjadi fasilitator sebagai penengah dalam memecahkan permasalahan atau memperjelas jawaban terhadap permasalahan.

Diskusi harus dilaksanakan secara terbuka, demokratis, dan humanis dalam rangka menggali kreativitas peserta didik saat mengikuti pembelajaran pendidikan agama Islam. Guru pendidikan agama Islam harus 
mendorong semua peserta didik untuk berpartisipasi memberikan pertanyaan dan tanggapan terhadap pernyataanpernyataan yang disampaikan oleh kelompok pemakalah terkait materi yang didiskusikan pada saat itu. Di bawah ini dapat diuraikan teknik penting yang harus dilalui dalam pelaksanaan metode diskusi dalam pembelajaran pendidikan agama Islam.

Keenam, menyimpulkan hasil diskusi. Pada siklus ini guru pendidikan agama Islam bersama dengan peserta didik menyimpulkan hasil diskusi. Tahap ini dilakukan setelah presentasi kelompok telah selesai dilangsungkan oleh suatu kelompok tertentu. Guru pendidikan agama Islam harus dapat menyimpulkan hasil diskusi yang telah dilangsungkan untuk memberikan penguatan terhadap hasil diskusi. Di samping itu juga adalah untuk menyesuaikan hasil diskusi yang telah dilakukan dengan tujuan pembelajaran yang telah ditetapkan sebelumnya.

Pada tahap ini hal yang dilakukan oleh seorang guru PAI dapat menggunakan langkah-langkah krusial, yaitu: (1) guru PAI meminta beberapa orang peserta didik untuk memberikan kesimpulan terhadap materi yang diajarkan dimulai dari masing-masing indikator pembelajaran; (2) meminta peserta didik yang lainnya untuk melengkapi kesimpulan yang telah dikemukakan peserta didik sebelumnya; (3) guru PAI bersama peserta didik mengklasifikasi kesimpulan tersebut sesuai dengan indikator pembelajaran; dan (4) meminta pada peserta didik untuk menuliskan garis besar kesimpulan pembelajaran sesuai dengan indikator pembelajaran pada kertas kerja mereka.

Ketujuh, melakukan evaluasi. Guru pendidikan agama Islam harus mampu melakukan evaluasi sebagai upaya memberikan umpan balik terhadap hasil diskusi yang telah dilaksanakan. Evaluasi diperlukan untuk mengetahui tingkat pemahaman dan penguasaan peserta didik terhadap materi yang diajarkan melalui metode diskusi tersebut. Di samping itu juga evaluasi diperlukan untuk memberikan umpan balik bagi guru terhadap efektifitas dan tingkat keberhasilan penggunaan metode yang dilangsungkan.

Hal ini perlu dilakukan agar guru pendidikan agama Islam dapat melakukan perbaikan terhadap penggunaan metode diskusi yang dilakukan. Hal inilah yang sering diabaikan oleh para guru pendidikan agama Islam saat ini. Mengabaikan evaluasi terhadap penggunaan metode yang dilakukan dan seringkali evaluasi ini hanya bagi tingkat penguasaan peserta didik terhadap materi pelajaran. Pola ini sesungguhnya sudah haru diperbaiki agar pembalajaran pendidikan agama Islam dari ke hari menunjukkan kualitas maksimal.

Pada siklus ini juga menjadi perhatian penting bagi guru pendidikan agama Islam di samping mengevaluasi tingkat penguasaan materi peserta didik juga adalah untuk mengevaluasi penggunaan metode yang dipergunakan. Hal ini pulalah yang sering diabaikan oleh seorang guru untuk memberikan umpan balik terhadap keberhasilan metode pembelajarannya. Dengan mengadakan evaluasi terhadap penguasaan materi peserta didik dan keberhasilan penggunaan metode maka guru pendidikan agama Islam akan selalu melakukan perbahan dan perbaikan terhadap proses pembelajaran yang dilangsungkan. Dampaknya proses pelaksanaan pembelajaran pendidikan agama Islam akan selalu berpacu dengan kualitas. Kualitas proses pembelajaran yang didasarkan pada keinginan untuk membangun peserta didik yang 
berkualitas dengan cara yang bijak, akuntabel, dan ikhlas.

\section{SIMPULAN}

Metode diskusi dalam pembelajaran pendidikan agama Islam adalah suatu cara penguasaan bahan pelajaran melalui tukar menukar pendapat antar peserta didik sesuai pengetahuan dan pengalaman didasarkan pada suasana demokratis dan humanis dalam memecahkan suatu masalah di bawah bimbingan guru untuk memperoleh keputusan bersama sesuai indikator pembelajaran yang telah ditetapkan.

Metode dikusi tersebut sangat tepat digunakan untuk beberapa hal berikut, yaitu; Pertama, saat guru PAI akan mengajarkan materi pembelajaran yang mengandung persoalan yang memungkinkan untuk diberikan kajian mendalam. Materi pembelajaran yang mengandung persoalan mungkin untuk dijadikan kajian merupakan materi yang sifatnya terbuka di mana para peserta didik memiliki ruang untuk mendiskusikannya. Kedua, materi yang berkaitan dengan persoalan-persoalan duniawi yang belum ditentukan petunjuknya di dalam al-Qur'an dan Sunnah Rasul SAW. Di sini dapat tergambarkan seperti yang telah disebutkan di atas, bahwa persoalanpersoalan yang telah ada petunjuknya dari Allah SWT secara tegas dan jelas, baik langsung maupun melalui Rasulullah SAW, persoalan itu tidak lagi termasuk yang dapat dimusyawarahkan. Ketiga, metode diskusi tepat digunakan apabila para peserta didik memiliki kecakapan dan sifat percaya diri dalam proses pembelajaran terkait dengan materi yang akan diajarkan. Penekanan di sini adalah di mana para peserta didik memiliki kecakapan materi dan kepercayaan diri dalam mengkomunikasikan pemikirannya pada khalayak ramai. Hal ini pulalah yang menjadi bagian penting, adanya kecakapan kepercayaan diri berkomunikasi pada diri peserta didik, mengapa metode diskusi ini dapat dipergunakan dalam proses pembelajaran.

Metode diskusi memiliki kelebihan dan kekurangan dalam proses pembelajaran PAI. Kelebihan metode diskusi adalah; (1) Dapat memperluas wawasan peserta didik; (2) Merangsang kreativitas peserta didik dalam memunculkan ide dalam memecahkan suatu masalah; (3) Dapat mengembangkan sikap menghargai pendapat orang lain; (4) Dapat menumbuhkan partisipasi peserta didik menjadi lebih aktif; (5) Merangsang peserta didik berfikir dan mengeluarkan pendapat sendiri. Sementera kelemahan metode diskusi tersebut adalah: (1) Kemungkin besar diskusi akan dikuasai oleh peserta didik yang suka berbicara atau ingin menonjolkan diri; (2) Tidak dapat dipakai pada kelompok yang besar; (3) Peserta mendapat informasi yang terbatas. Metode diskusi yang dipergunakan dalam pembelajaran PAI akan membuat informasi hanya terbatas sesuai dengan tema diskusi; (4) Menyerap waktu yang cukup banyak; dan (5) Tidak semua guru memahami cara peserta didik melakukan diskusi.

Terdapat tujuh langkah penting dalam metode diskusi sekaligus sebagai sebagai panduan bagi guru pendidikan agama Islam dalam menjalankannya pada setiap pembelajaran pendidikan agama Islam yang dilangsungkan, yaitu: (1) Merumuskan tujuan pembelajaran dengan menggunakan metode diskusi; (2) Menentukan mekanisme dan tata tertib diskusi; (3) Merumuskan masalah atau topik yang akan didiskusikan; (4) mengatur kelompok-kelompok diskusi; (5) Langkah kelima, melaksanakan 
diskusi; (6) Menyimpulkan hasil diskusi; dan (7) Melakukan evaluasi.

\section{DAFTAR RUJUKAN}

Ahmadi, Abu. 1986. Metode Khusus Pendidikan Agama Islam. Jakarta: Bima Aksara.

Al-Darimi, Abi Muhammad Abdillah bin Abdurrahman bin Bahram. t.t. Sunan al-Darimi, Juz 1. Beirut: Dar al-Fikr.

Daradjat, Zakiah, et al., 2001. Metodik Khusus Pendidikan Agama Islam, Jakarta: Bumi Aksara. cet. Ke- 2.

Dimyati dan Mudjiono. 2003. Belajar dan Pembelajaran. Jakarta: Rineka Cipta.

Oemar, Hamalik. 2001. Proses Belajar Mengajar. Jakarta: Bumi Aksara.

K., Roestiyah N., 1991. Strategi Belajar Mengajar. Jakarta: Rineka Cipta. Cet. ke -4 .

Shihab, M. Quraish. 2002. Tafsir alMishbah; Pesan, Kesan, dan Keserasian al-Qur'an, Volume 2. Jakarta: Lentera Hati.
Nizar, Samsul dan Zainal Efendi Hasibuan. 2011. Hadis Tarbawi: Membangun Kerangka Pendidikan Ideal Perspektif Rasulullah, Jakarta: Kalam Mulia. Cet. Ke- 1.

Nizar, Samsul. 2008. Memperbincangkan Dinamika Intelektual dan Pemikiran HAMKA tentang Pendidikan Islam. Jakarta: Prenada Media Group. Cet. Ke-1.

Shaleh, Abdul Rachman. 2006. Pendidikan Agama Islam dan Pembangunan Watak Bangsa. Jakarta: Raja Grafindo Persada.

Sudjana, Nana. 1995. Dasar-Dasar Proses Belajar Mengajar. Bandung: Sinar Baru Algesindo Offset. cet. ke -3

- Tambak, Syahraini "Merajut Pendidikan Demokratis Humanis", Harian Umum Pelita, Jakarta, 2006.

Tim Penyusun Kamus Pusat Bahasa, Kamus Besar Bahasa Indonesia,ed. 3, Jakata: Balai Pustaka, 2005

Yamin, Martinis. 2011. Strategi Pembelajaran Berbasis Kompetensi. Saiful Ibad (ed.). Jakarta: RajaGrafindo Persada. 